\title{
Ground beetles (Coleoptera: Carabidae) as predators of conifer seeds
}

\author{
Zdenka Martinková ${ }^{1 *}$, Stanislava Koprdová ${ }^{1}$, Ján Kulfan $^{2}$, Peter Zach², Alois Honěk ${ }^{1}$ \\ ${ }^{1}$ Crop Research Institute, Drnovská 507, CZ 16106 Praha 6 - Ruzyně, Czech Republic \\ ${ }^{2}$ Institute of Forest Ecology, Slovak Academy of Sciences, L. Štúra 2, 96053 Zvolen, Slovak Republic
}

\begin{abstract}
Martinková, Z., Koprdová, S., Kulfan, J., ZaCh, P., HonĚK, A., 2019. Ground beetles (Coleoptera: Carabidae) as predators of conifer seeds. Folia Oecologica, 46: 37-44.

Many species of ground beetles (Coleoptera: Carabidae) are important predators of seeds. While the consumption of herb seeds has been intensively studied, little attention has been paid to the consumption of seeds of gymnosperm plants. Here, we determined the consumption of seeds of six coniferous species by four common carabid species and compared carabid preference for conifer and selected common angiosperm weed seed species. In no-choice experiments, the large carabid species Pseudoophonus rufipes preferentially consumed the seeds of Picea abies, Larix decidua and Pinus sylvestris. Pinus sylvestris was also preferred by another large carabid, Pterostichus melanarius. The smaller carabids Harpalus affinis and H. rubripes consumed conifer seeds reluctantly. The intensity of seed consumption by carabids decreased with increasing seed size. In choice experiments, both of the large carabid species preferred the small conifer seeds of $P$. sylvestris and L. decidua over herb seeds of similar size (Dipsacus fullonum, Galeopsis speciosa, Polygonum lapathifolium). Carabids may prefer conifer seeds because of their soft seed coats, regardless of their chemical protections. Postdispersal predation of seeds by carabids may be an important mortality factor in some conifer species.
\end{abstract}

\section{Keywords}

angiosperms, gymnosperms, seed consumption, seed size

\section{Introduction}

Predation of seeds scattered on the ground surface after dispersal from mother plants is a common phenomenon and an important factor of plant mortality (HARPER, 1977; Silvertown and Charlesworth, 2001). Seeds that are spread on the ground before germination or entering the soil are exposed to a wide array of vertebrate (birds and mammals) and invertebrate (beetles, crickets, ants and moth larvae) predators (WESTERMAN et al., 2003). In Central Europe, the dominant invertebrate seed predators are ground beetles (Coleoptera: Carabidae) (HoneK et al., 2003). Many carabid species consume seeds in both the lar- val (SASKA and JAROSIK, 2001) and adult stages (HoNEK et al. 2005, 2009). For many species of the tribes Zabrini and Harpalini, seeds are their main food item, while for many species of tribes Pterostichini, Platynini and Trechini, seeds represent only a welcome food supplement (HoNEK et al., 2007) or a "non-prey" food (LUNDGREN, 2009; TALARICO et al., 2016). Carabid preferences for seed species and the quantity of consumed seeds depend on several factors. In addition to the taxonomic affiliation of carabids, a limiting factor of seed consumption is the ratio of seed size to carabid size and toughness of the seed coat. Soft seeds with a size that is proportional to the dimensions of carabid mouthparts are preferred, whereas seeds that are too small

*Corresponding author:

e-mail: martinkova@vurv.cz 
or too large compared to carabid dimensions and seeds with hard and smooth coats are neglected (LUNDGREN and ROSENTRATER, 2007). In addition, seed consumption varies with the course of the season (HoNEK et al., 2006) and with actual temperature (SASKA et al., 2010). Carabid seed predation has been intensively studied in relation to weed control and the seeds of herbs (KULKARNI et al., 2015). In contrast, the consumption of conifer seeds has been the subject of few works that have either established the occurrence of predation directly (NYSTRAND and GRANSTROM, 2000) or on the basis of indirect evidence (CôTÉ et al., 2005; Frei et al., 2012; Kambo and DanBy, 2018). These works have indicated that predation of conifer seeds by carabids is massive and has practical consequences because seed predation may remove or damage a large proportion of dispersed seeds. In addition (but no less theoretically interesting), studies on conifer seed predation may reveal coherence in seed predator preferences (e.g., for particular seed size) despite phylogenetic differences between seed taxa.

In this study, we investigated the preferences of four carabid species for six species of conifer seeds. We selected species of carabids that were likely seed eating. We selected representatives of the tribes Harpalini and Pterostichini, in particular, due to their large body sizes, and we selected the seeds of common conifer species that differed in size. We tested three hypotheses based on our earlier experimental experience on the predation of herb seeds: (1) The intensity of seed predation depends on the carabid taxonomic affiliation rather than on their body size, i.e., species of Harpalini are more efficient predators than species of Pterostichini. (2) The size of the conifer seeds is a more important factor of seed consumption than seed taxonomic affiliation. (3) The seeds of conifer species (gymnosperms) are less attractive to predators than the seeds of dicotyledonous weeds (angiosperms) because gymnosperms, during their longer evolutionary history, may have had greater opportunity to develop protective adaptations against seed predation than angiosperm plants.

\section{Materials and methods}

\section{Seed species}

The seeds (Table 1) of six species of conifer trees and three species of wild herbs found frequently growing on the clearings and margins of conifer forests were used in this study. Conifer seeds were purchased from Semenáŕský závod (Týniště nad Orlicí, www.semenarskyzavod. cz), except for seeds of Thuja occidentalis, which were collected from trees growing at the Crop Research Institute v. v.i. at Prague-Ruzyne (50.086N, 14.303E). The herb seeds were collected at sites located within the $5 \times 5 \mathrm{~km}$ quadrat centred on $50.115 \mathrm{~N}, 14.265 \mathrm{E}$, during the year before the experiments were conducted. The seeds were stored dry at $5{ }^{\circ} \mathrm{C}$ from the time of purchase or collecting until experimentation. The seed length and width were measured as the median values of the seed dimensions, indicated by BoJNANSKY and FARGaSOva (2007). The volume (V) of the seeds was approximated as being three axis ellipsoids calculated by the equation: $\mathrm{V}=4 / 3 \pi \mathrm{abc}$, where $\mathrm{a}=1 / 2$ seed length, $b=1 / 2$ seed width, $c=1 / 2$ seed width $\times 0.2$ in conifer seeds or $c=1 / 2$ seed width in herb seeds. The average seed mass was determined by weighing five samples of 50 seeds used in the experiments.

Table 1. Seed species used in the experiment and their morphometry

\begin{tabular}{|c|c|c|c|c|}
\hline Species & $\begin{array}{c}\text { Length } \\
(\mathrm{mm})\end{array}$ & $\begin{array}{l}\text { Width } \\
(\mathrm{mm})\end{array}$ & $\begin{array}{c}\text { Volume } \\
\left(\mathrm{mm}^{3}\right)\end{array}$ & $\begin{array}{l}\text { Mass } \\
(\mathrm{mg})\end{array}$ \\
\hline \multicolumn{5}{|l|}{ Gymnosperms } \\
\hline $\begin{array}{c}\text { Cupressaceae } \\
\text { Thuja occidentalis L. }\end{array}$ & 6.0 & 3.0 & 5.7 & 6.3 \\
\hline Abies alba Mill. & 11.0 & 6.0 & 41.5 & 51.8 \\
\hline Larix decidua Mill. & 4.0 & 2.4 & 2.3 & 5.0 \\
\hline Picea abies (L.) Karst. & 4.5 & 2.5 & 2.9 & 7.0 \\
\hline Pinus sylvestris L. & 4.0 & 2.9 & 3.4 & 6.4 \\
\hline Pseudotsuga menziesii (Mirbel) Franco & 6.0 & 3.5 & 7.7 & 12.2 \\
\hline \multicolumn{5}{|l|}{ Angiosperms } \\
\hline Dipsacaceae & & & & \\
\hline Dipsacus fullonum $\mathrm{L}$. & 4.7 & 1.5 & 5.5 & 4.5 \\
\hline Lamiaceae & & & & \\
\hline Galeopsis speciosa Mill. & 2.8 & 2.3 & 7.6 & 3.7 \\
\hline $\begin{array}{c}\text { Polygonaceae } \\
\text { Polygonum lapathifolia (L.) Delarbre }\end{array}$ & 2.5 & 2.0 & 2.6 & 2.0 \\
\hline
\end{tabular}




\section{Carabid species}

Four carabid (Coleoptera: Carabidae) species, Harpalus affinis (Schrank), H. rubripes (Duftschmid), Pterostichus melanarius (Illiger) and Pseudoophonus rufipes (DeGeer), were selected as seed predators (Table 2). The average body lengths of these species were taken from HuRKA (1996), and their dry body masses were calculated using the formula of Rogers et al. (1976) and JAROSIK (1989). Experimental beetles were collected at the ground of Crop Research Institute v.v.i. at Prague-Ruzyne using pitfall traps. The pitfall traps, plastic cups that were $8 \mathrm{~cm}$ deep with a $7 \mathrm{~cm}$ orifice diameter, were placed in stands of winter rape and winter wheat. The adult carabids were stored in the laboratory for 3-5 days in the dark at temperatures of $5-7{ }^{\circ} \mathrm{C}$. This treatment standardised beetle hunger levels, and low temperatures prevented cannibalism. The beetles were then removed from the cold and randomly assigned to preference experiments.

Table 2. Carabid species used in the experiments, their mean body length after HURKA (1996) and dry body mass calculated from mean body length using the formula of RogERs et al. (1976)

\begin{tabular}{ccc}
\hline Species & $\begin{array}{c}\text { Body length } \\
(\mathrm{mm})\end{array}$ & $\begin{array}{c}\text { Dry body } \\
\text { mass }(\mathrm{mg})\end{array}$ \\
\hline $\begin{array}{c}\text { Harpalini } \\
\text { Harpalus affinis } \\
\quad \text { Schrank) }\end{array}$ & 10.2 & 13.4 \\
$\begin{array}{c}\text { Harpalus rubripes } \\
\text { (Duftschmid) }\end{array}$ & 10.3 & 13.7 \\
$\begin{array}{c}\text { Pseudoophonus rufipes } \\
\text { (DeGeer) }\end{array}$ & 13.8 & 29.6 \\
$\begin{array}{c}\text { Pterostichini } \\
\text { Pterostichus melanarius } \\
\text { (Illiger) }\end{array}$ & 15.7 & 41.5 \\
\hline
\end{tabular}

\section{Feeding experiments}

Seed feeding experiments were performed between 20 and 30 June 2009. The ground was covered by dry soil, and water was provided on a moist piece of cotton that was placed on a piece of aluminium foil to prevent moistening of the soil. The seeds were presented on a round filter paper sheet of $4 \mathrm{~cm}$ diameter that was then placed in the centre of a glass Petri dish ( $9 \mathrm{~cm}$ diameter, $1.8 \mathrm{~cm}$ high). At the start of the no-choice experiment, 10 seeds of a single conifer species and one individual of a carabid species were placed in each Petri dish. The experiments were conducted for 3 days. The number of consumed seeds was recorded each day, and fresh seeds were replenished if 50\% of seeds were eaten. A seed was considered fully eaten if it was removed from the round paper pad and $\geq 50 \%$ of its volume was eaten. At the start of dual-choice experiments, 10 conifer seeds, 10 herb seeds and one carabid individual were presented in each Petri dish.

\section{Data analysis}

In each experiment, the average number of consumed seeds ( \pm SE) (seed consumption) was calculated for each seed and carabid species combination.

Data on average seed consumption were standardised as follows: $\mathrm{C}_{\mathrm{s}}=\left(\mathrm{x}_{\mathrm{o}}-\mathrm{x}_{\mathrm{a}}\right) / \mathrm{s}_{\mathrm{x}}$ where $\mathrm{C}_{\mathrm{s}}=$ the standardised value of consumption of a seed species by a particular carabid species; $x_{0}=$ the experimental value of the average consumption of seed species by a particular carabid species; $x_{a}=$ the greatest average of seed consumption by all carabid species combined; $\mathrm{s}_{\mathrm{x}}=$ the standard deviation of the greatest average of carabid consumption of seed species (HENDL, 2009). The relationship between seed size and carabid consumption was calculated as a regression of the standardised seed consumption on log seed volume or log seed mass. The differences in the consumption of seeds of Cupressaceae and Pinaceae families were tested using ANOVA with the residuals of standardised consumption of a seed species from a common log-normal plot (Fig. 1a) as the response variable and the seed family as a factor.

The relationship between carabid body mass and seed consumption was calculated as a regression of log seed consumption on log carabid body mass using the data for seeds with non-zero consumption.

\section{Results}

In the no-choice experiments, the numbers of seeds eaten varied with the seed and carabid species (Table 3 ). The preferred seed species ( $>5$ seeds per individual eaten in the 3-day experiment) were $L$. decidua, $P$. abies and $P$. sylvestris. Seeds of $P$. menziesii were accepted reluctantly, while seeds of $A$. alba and T. occidentalis were rejected. The standardised consumption of seeds $\left(\mathrm{C}_{\mathrm{S}}\right)$ decreased with increasing seed volume $(\mathrm{V})\left(\right.$ Fig. $1 \mathrm{a}, \mathrm{C}_{\mathrm{S}}=0.759-$ $\left.(1.164 \times \log \mathrm{V}), \mathrm{R}^{2}=0.412, \mathrm{~F}_{1,23}=15.397, P<0.001\right)$. The ANOVA revealed that the consumption of $T$. occidentalis (Cupressaceae) seeds was significantly lower than the value expected for a Pinaceae seed species of similar size. In contrast, the consumption of the Pinaceae seed species ( $A$. alba, L. decidua, P. abies, P. menziesii and P. sylvestris) did not differ from the common trend of the regression for standardised seed consumption on log seed volume. The standardised consumption of seeds was less strongly, but still significantly, correlated with the seed mass $\mathrm{M}_{\mathrm{S}}$ (Fig. $1 b, C=1.515-(1.120 \times \log \mathrm{M}), \mathrm{R}^{2}=0.260 ; \mathrm{F}_{1,23}=7.711$, $P=0.011)$.

The species of ground beetles differed in their consumption activities (Table 3 ). The most voracious were the two large species; P. rufipes, which consumed all accepted species of seeds, and $P$. melanarius, which consumed seeds of $P$. sylvestris, each at a high rate ( $>5$ seeds per individual eaten in a 3-day experiment). $P$. rufipes also consumed the seeds of $P$. menziesii, and $P$. melanarius consumed the seeds of $P$. abies and $P$. menziesii, each at a medium rate ( $\geq 2$ seeds per individual eaten in the 3 -day experiment). 
Table 3. Consumption of seeds of six conifer species by four species of carabids in a three-day, no-choice experiment

\begin{tabular}{|c|c|c|c|c|}
\hline Seed species & Carabid species & $\mathrm{N}$ & Mean \pm SE & Min-Max \\
\hline \multicolumn{5}{|l|}{ Cupressaceae } \\
\hline \multirow[t]{4}{*}{ Thuja occidentalis } & H. affinis & 10 & $0.0 \pm 0.00$ & $0-0$ \\
\hline & H. rubripes & 10 & $0.1 \pm 0.10$ & $0-1$ \\
\hline & P. rufipes & 10 & $0.1 \pm 0.10$ & $0-1$ \\
\hline & P. melanarius & 10 & $0.0 \pm 0.00$ & $0-0$ \\
\hline \multicolumn{5}{|l|}{ Pinaceae } \\
\hline \multirow[t]{4}{*}{ Abies alba } & H. affinis & 10 & $0.0 \pm 0.00$ & $0-0$ \\
\hline & H. rubripes & 10 & $0.0 \pm 0.00$ & $0-0$ \\
\hline & P. rufipes & 10 & $0.0 \pm 0.00$ & $0-0$ \\
\hline & P. melanarius & 10 & $0.0 \pm 0.00$ & $0-0$ \\
\hline \multirow[t]{4}{*}{ Larix decidua } & H. affinis & 10 & $2.4 \pm 1.25$ & $0-12$ \\
\hline & H. rubripes & 10 & $0.5 \pm 0.22$ & $0-2$ \\
\hline & P. rufipes & 10 & $10.4 \pm 1.08$ & $5-14$ \\
\hline & P. melanarius & 10 & $0.3 \pm 0.15$ & $0-1$ \\
\hline \multirow[t]{4}{*}{ Picea abies } & H. affinis & 10 & $1.0 \pm 0.39$ & $0-3$ \\
\hline & H. rubripes & 10 & $1.2 \pm 0.47$ & $0-4$ \\
\hline & P. rufipes & 10 & $8.1 \pm 1.04$ & $4-14$ \\
\hline & P. melanarius & 10 & $2.4 \pm 0.48$ & $0-4$ \\
\hline \multirow[t]{4}{*}{ Pinus sylvestris } & H. affinis & 10 & $2.0 \pm 0.60$ & $0-5$ \\
\hline & H. rubripes & 10 & $1.7 \pm 0.52$ & $0-5$ \\
\hline & P. rufipes & 10 & $8.7 \pm 2.02$ & $0-22$ \\
\hline & P. melanarius & 10 & $7.1 \pm 1.29$ & $2-14$ \\
\hline \multirow[t]{4}{*}{ Pseudotsuga menziesii } & H. affinis & 10 & $1.1 \pm 0.31$ & $0-3$ \\
\hline & H. rubripes & 10 & $0.5 \pm 0.22$ & $0-2$ \\
\hline & P. rufipes & 10 & $2.6 \pm 0.31$ & $1-4$ \\
\hline & P. melanarius & 10 & $2.8 \pm 0.25$ & $2-4$ \\
\hline
\end{tabular}

$\mathrm{N}$, the number of replicates; mean $\pm \mathrm{SE}$, the mean and standard error of seeds consumed per individual carabid during the threeday experiment; Minimum (Min) and Maximum (Max) are the respective numbers of seeds consumed in particular replicates.
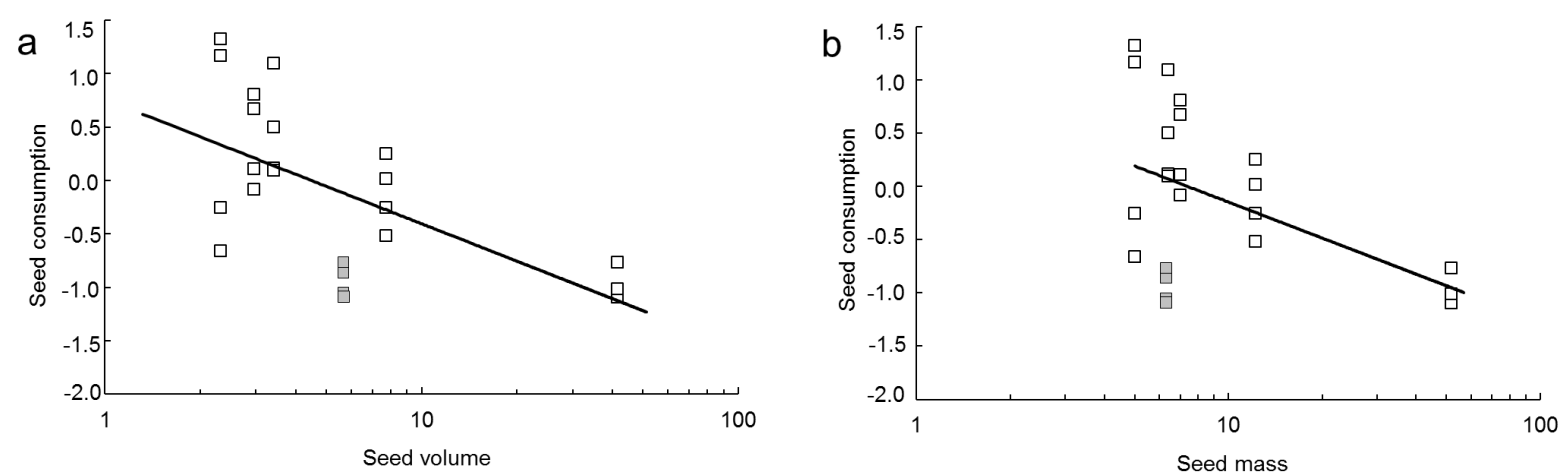

Fig. 1. Standardised seed consumption plotted against (a) log seed volume ( $\left.\mathrm{mm}^{3}\right)$ and (b) seed mass (mg). Each seed species is represented by a vertical row of four quadrats representing consumption by a particular species of carabid. $\square$ Open quadrats: Larix decidua, Picea abies, Pinus sylvestris, Pseudotsuga menziesii and Abies alba, - closed quadrats: Thuja occidentalis.

The small species of carabids were poor seed consumers; Harpalus affinis consumed the seeds of L. decidua, P. sylvestris, $P$. abies and $P$. menziesii, each at a low rate $(\geq 1$ seed per individual eaten in 3-day experiment). Harpalus rubripes only consumed the seeds of two species, $P$. abies and $P$. sylvestris, each at a low rate. The consumption (C) of accepted seeds increased with carabid body mass $\mathrm{M}_{\mathrm{C}}$ (Fig. $2, \log \mathrm{C}=-1.521+\left(1.425 \times \log \mathrm{M}_{\mathrm{C}}\right), \mathrm{R}^{2}=0.513, \mathrm{~F}_{1,14}$ $=13.702, P=0.003)$.
In the dual-choice experiments, both large carabid species preferred conifer seeds over the seeds of herbs. Pseudoophonus pubescens preferred the seeds of $L$. decidua over the seeds of $G$. speciosa and D. fullonum, while the difference in consumption of $L$. decidua and P. lapathifolium seeds was not significant (Table 4). Pterostichus melanarius preferred the seeds of $P$. sylvestris over the seeds of all offered herbs (G. speciosa, D. fullonum and $P$. lapathifolium) (Table 4). 
Table 4. Consumption of seed species in dual-choice experiments

\begin{tabular}{lccc}
\hline & Mean \pm SE & Min-Max & $P$ \\
\hline Pseudoophonus rufipes & & & \\
1. Larix decidua & $12.5 \pm 1.15$ & $6-6$ & $<0.001$ \\
$\quad$ Galeopsis speciosa & $0.0 \pm 0.00$ & $0-0$ & $\mathrm{NS}$ \\
2. Larix decidua & $12.6 \pm 1.71$ & $5-22$ & \\
$\quad$ Polygonum lapathifolium & $8.6 \pm 1.75$ & $2-19$ & $<-18$ \\
3. Larix decidua & $12.6 \pm 1.25$ & $0-5$ & \\
Dipsacus fullonum & $1.7 \pm 0.60$ & & $<0.001$ \\
Pterostichus melanarius & & $3-11$ & \\
4. Pinus sylvestris & $6.9 \pm 1.00$ & $0-3$ & 0.004 \\
Galeopsis speciosa & $0.8 \pm 0.33$ & $0-12$ & $<0.001$ \\
5. Pinus sylvestris & $6.2 \pm 1.48$ & $0-2$ & \\
Polygonum lapathifolium & $0.7 \pm 0.29$ & $3-12$ & \\
Dinus sylvestris & $9.1 \pm 1.03$ & $0-1$ & \\
\hline
\end{tabular}

The six pairs of compared seed species are indicated by serial numbers 1 to 6 . The feeding experiment lasted for 3 days, and each seed pair was replicated 10 times. The table indicates the mean number of consumed seeds $( \pm \mathrm{SE})$, the minimum and maximum numbers of consumed seeds in particular replicates, and the significance of the difference in the number of consumed seeds between the two compared species.

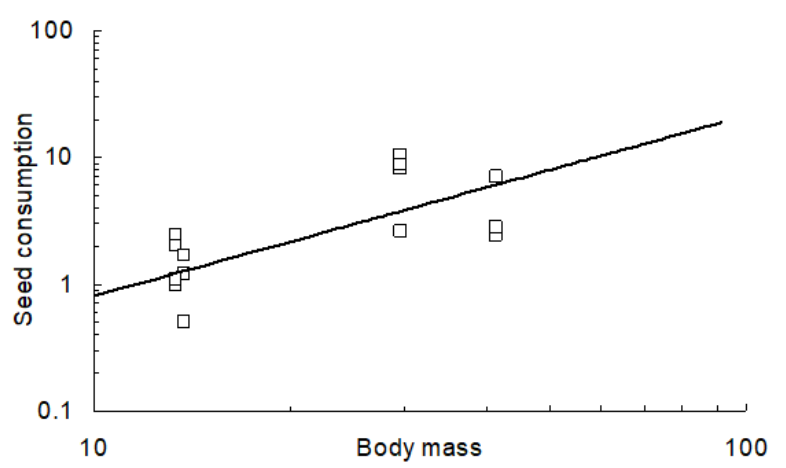

Fig. 2. Consumption of preferred seeds related to body mass of the carabid species.

\section{Discussion}

\section{Predation of conifer seeds}

After dispersal from mother plants, seeds are consumed by a variety of vertebrate and invertebrate predators (WESTERMAn et al., 2003; Kitajima, 2007). Among the invertebrate predators of Central Europe, the most important are ground beetles. This is because of their relatively large body size, which enables the consumption of seeds of many plant species, while other native seed predators, isopods (SASKA, 2008) and millipedes (KoPRDOva et al., 2010), specialise in the consumption of small seeds. Other large and voracious seed predators, crickets (O'RourKE et al., 2006; White et al., 2007; ICHIHARA et al., 2014) and seed-eating ants (CHAUHAN et al., 2010; BARAIBAR et al., 2011), are abundant only in southern, warm areas. Carabids are thus apparently the most efficient inverte- brate consumers of conifer seeds in Central Europe, and the results of this study are worth theoretical and practical consideration.

This study tested three hypotheses. Hypothesis (1) predicted that the intensity of seed predation depends more on carabid taxonomic affiliation than on their body size, i.e., the species of Harpalini are more efficient predators than the species of Pterostichini (HonEK et al., 2003). Both large carabid species consumed seeds eagerly, and P. rufipes (Harpalini) consumed more than P. melanarius (Pterostichini). On the other hand, the seed consumption of the two small Harpalini species was low. The intensity of seed consumption was thus determined more by carabid body size than taxonomic affiliation. However, P. melanarius eagerly consumed only the species of conifer seeds and rejected the seeds of dicotyledonous herbs (cf. HoNEK et al., 2003). The preference of Pterostichini species thus might be limited by the taxonomic affiliation of seeds. $\mathrm{Pu}-$ blished data support this conclusion since several Pterostichini species were previously established as predators of conifer seeds: Pterostichus adstrictus (Eschscholtz), Pterostichus punctatissimus (Randall) (CôTÉ et al., 2005) and Pterostichus oblongopunctatus (Fabricius) (Nystrand and Granstrom, 2000). Calathus micropterus (Duftschmidt) of the tribe Platynini was also suspected of seed predation (NySTRAND and GRANSTROM, 2000). It is thus possible that Pterostichus species, which are not efficient predators of small herb seeds, prefer other seeds that have not yet been offered in experiments. The diet specialisation of $P$. melanarius is also indicated by its preference for seeds of winter oilseed rape (Brassica napus L. ssp. napus), which were rejected by other carabid seed predators (HoNEK and MartinKova, 2001; Koprdova et al., 2008; Koprdova et 
al., 2012). Hypothesis (1) was thus partly falsified because the Pterostichini species, P. melanarius, is an eager predator of conifer seeds. This points to the necessity of further research into the specificity of the preferences of carabid seed predators.

Hypothesis (2) predicted that the size of conifer seeds is a more important factor of seed consumption than seed taxonomic affiliation. The seed consumption data of Pinaceae fit the hypothesis perfectly. In contrast, the seeds of Cupressaceae (T. occidentalis) were rejected despite their convenient, small size, apparently because of the seeds' high content of secondary defence metabolites (NASER et al., 2005). This family-specific difference in the acceptance of conifer seeds indicates that the hypothesis of a negative correlation between seed size and consumption rate may be falsified if the seeds of species of different taxonomic affiliations are offered. This again points to the necessity of further research into the specificity of the preferences of carabid seed predators.

Hypothesis (3) predicted that the seeds of conifer species (gymnosperms) are less attractive to predators than seeds of dicotyledonous weeds (angiosperms) since the longer evolutionary history of gymnosperms provided an opportunity to evolve more efficient anti-predation adaptations than angiosperms. This speculation was falsified because in five of the six preference experiments, the conifer seeds were significantly preferred over the seeds of dicotyledonous herbs. Again, more experiments are necessary to test differences in carabid consumption of gymnosperm and angiosperm seeds.

Efficiency of predation in the open and conifer seed mortality

Small conifer seeds of A. alba, L. decidua and P. abies were consumed by large species of seed-eating carabids of both Harpalini (P. rufipes) and Pterostichini (P. melanari$u s$ ) but were rejected by small carabid species. Both large carabid species selected for the experiments are ubiquists that occur in forest margins and may spread into their interiors (Thomas et al., 1997; HoneK and Kocian, 2003), contributing to the mortality of conifer seeds. The small Harpalus species included in the experiment are typically found in open landscapes (HuRKA, 1996) but may also enter the forest margins, if not the forest itself. However, they are inefficient seed predators because of their small size. The typical carabid inhabitants of forests are mostly poor seed predators (LoREAU, 1992). Carabid communities inhabiting conifer forests are poor compared to those in deciduous or mixed forests (OxBrough et al., 2016). The carabid communities in European coniferous forests have been extensively studied and consist of the genera Abax, Calathus, Carabus, Cychrus, Leistus, Loricera, Molops, Nebria, Notiophilus, Patrobus, Pseudoophonus, Pterostichus and Trechus (Jukes et al., 2001; MAGURA et al., 2002; KoIvula et al., 2004; SAINT-Germain et al., 2005; GongALSKY et al., 2006; BARSOUM et al., 2014; JoHANSSON et al., 2016; LANGRAF et al., 2017). The genera
Pseudoophonus, Pterostichus, Calathus and Trechus have already been shown to be seed predators (HoNEK et al., 2003). The potential of carabid species inhabiting forest interiors for conifer seed predation should be investigated using more species of both seeds and predators.

These potential seed feeders may not be deterred from the predation of conifer seeds by the presence of herb seeds. The herb seed species provided to the carabids in our experiments were selected from the wide variety of seed species that may be encountered in forests because their size was similar to the size of the preferred conifer seed species. The provided seed species were rejected, but many other herbaceous seed species may compete for carabid preference in forests and their margins. It would be interesting to compare the preferences for small herbaceous seed species compared to conifer seed species. Preferred herb seed species, such as Capsella bursa-pastoris, Viola spp. and Taraxacum agg. (HoneK et al., 2007), may attract carabids more than the herb species used in these experiments and possibly even more than the conifer seed species. The temporal distribution of seed production is important for seed predation. While conifer seeds are liberated from mother trees and persist on the ground surface for a long time, preferred herb seeds are dispersed during a short period of seed maturation, which usually does not exceed a few weeks at one patch. This long-term presence on the ground surface may make conifer seeds more vulnerable to invertebrate predation than angiosperm herb seeds.

In this work, we established that small species of conifer seeds are eaten by large carabid species. Seed predation by carabids may be an important mortality factor of conifer seeds. The actual consumption rates of conifer seeds in the open should be studied more, with respect to the composition of carabid communities, the role of the parallel presence of animal prey items, the seasonal variation of predation rates and the selection of seeds in multichoice conditions.

\section{Acknowledgements}

We thank Mrs. Jana Kohoutová and Mrs. Helena Uhlířová for excellent technical assistance. ZM and AH were supported by institutional support no. RO0418 of The Ministry of Agriculture of the Czech Republic and ZM by grant no. GA17-00043S of the Czech Science Foundation. JK and PZ were supported by grants VEGA 2/0012/17 and VEGA 2/0032/19 of the Scientific Grant Agency of the Ministry of Education, Science, Research and Sport of the Slovak Republic and the Slovak Academy of Sciences.

\section{References}

Baraibar, B., Ledesma, R., Royo-Esnal, A., Westerman, P.R., 2011. Assessing yield losses caused by the harvester ant Messor barbarus (L.) in winter cereals. Crop Protection, 30: 1144-1148. 
Barsoum, N., Fuller, L., Ashwood, F., Reed, K., BonnetLebrun, A.S., Leung, F., 2014. Ground-dwelling spider (Araneae) and carabid beetle (Coleoptera: Carabidae) community assemblages in mixed and monoculture stands of oak (Quercus robur L./Quercus petraea (Matt.) Liebl.) and Scots pine (Pinus sylvestris L.). Forest Ecology and Management, 321: 29-41.

Bojnansky, V., Fargasova, A., 2007. Atlas of seeds and fruits of Central and East-European flora. Dordrecht: Springer. $1046 \mathrm{p}$.

Chauhan, B.S., Migo, T., Westerman, P.R., Johnson, D.E., 2010. Post-dispersal predation of weed seeds in rice fields. Weed Research, 50: 553-560.

CôTÉ, M., FERron, J., GAGNON, R., 2005. Invertebrate predation of postdispersal seeds and juvenile seedlings of black spruce (Picea mariana) in the boreal forest of eastern Canada. Canadian Journal of Forest Research, 35: 674-681.

Frei, E.S., Scheepens, J.F., Stocklin, J., 2012. Dispersal and microsite limitation of a rare alpine plant. Plant Ecology, 213: 395-406.

Gongalsky, K.B., MidtgaArd, F., OvergaArd, H.J., 2006. Effects of prescribed forest burning on carabid beetles (Coleoptera: Carabidae): a case study in southeastern Norway. Entomologica Fennica, 17: 325-333.

Harper, J.L., 1977. Population biology of plants. London, New York, San Francisco: Academic Press. xxii +892 p.

HendL, J., 2009. Přehled statistických metod: analýza a metaanalýza dat [Statistical methods: analysis and metaanalysis of data]. Praha: Portal. 696 p.

HoneK, A., Kocian, M., 2003. Importance of woody and grassy areas as refugia for field Carabidae and Staphylinidae (Coleoptera). Acta Societatis Zoologicae Bohemicae, 67: 71-81.

HoneK, A., Martinkova, Z., 2001. Aggregation of ground beetles (Carabidae, Coleoptera) on winter rape seeds dispersed on the ground. Plant Protection Science, 37: 97-102.

Honek, A., Martinkova, Z., Jarosik, V., 2003. Ground beetles (Carabidae) as seed predators. European Journal of Entomology, 100: 531-544.

Honek, A., Martinkova, Z., Saska, P., 2005. Post-dispersal seed predation of Taraxacum officinale (dandelion) seed. Journal of Ecology, 93: 345-352.

Honek, A., MartinKova, Z., Saska, P., Koprdova, S., 2009. Role of post-dispersal seed and seedling predation in establishment of dandelion (Taraxacum agg.) plants. Agriculture Ecosystems and Environment, 134: 126-135.

Honek, A., Martinkova, Z., Saska, P., Pekar, S., 2007. Size and taxonomic constraints on seed consumption by adult Carabidae (Coleoptera). Basic and Applied Ecology, 11: $1-11$

Honek, A., Saska, P., Martinkova, Z., 2006. Seasonal variation in seed predation by adult carabid beetles. Entomologia Experimentalis et Applicata, 118: 157-162.

HurKa, K., 1996. Carabidae of the Czech and Slovak Republics. Zlín: Kabourek. 565 p.

Ichihara, M., Inagaki, H., Matsuno, K., Saiki, C., Mizumото, S., Yamaguchi, S., Yamashita, M., Sawada, H., 2014. Postdispersal weed seed predation by crickets in a rice paddy field after irrigation water recedes. JARQ - Japan Agricultural Research Quarterly, 48: 63-69.

JAROSIK, V., 1989. Mass vs. length relationship for carabid beetles (Col., Carabidae). Pedobiologia, 33: 87-90.

Johansson, T., Huältén, J., Olsson, J., Dynesius, M., RoBERGE, J.M., 2016. Long-term effects of clear-cutting on epigaeic beetle assemblages in boreal forests. Forest
Ecology and Management, 359: 65-73.

Jukes, M.R., Peace, A.J., Ferris, R., 2001. Carabid beetle communities associated with coniferous plantations in Britain: the influence of site, ground vegetation and stand structure. Forest Ecology and Management, 148: 271-286.

Kambo, D., Danby, R.K., 2018. Constraints on treeline advance in a warming climate: a test of the reproduction limitation hypothesis. Journal of Plant Ecology, 11: 411-422.

Kitajima, K., 2007. Seed and seedling ecology. In Pugnaire F.I., Valladares F. (eds). Functional plant ecology. Boca Raton, London, New York: CRC Press Taylor \& Francis Group, 2007, p. 549-579.

Koivula, M., HyyryläInen, V., Soininen, E., 2004. Carabid beetles (Coleoptera: Carabidae) at forest-farmland edges in southern Finland. Journal of Insect Conservation, 8: 297-309.

Koprdova, S., Saska, P., HoneK, A., Martinkova, Z., 2010. Seed consumption by millipedes. Pedobiologia, 54: 31-36.

Koprdova, S., Saska, P., Honek, A., Martinkova, Z., 2012. Susceptibility of the early growth stages of volunteer oilseed rape to invertebrate predation. Plant Protection Science, 48: 44-50.

Koprdova, S., SASKa, P., SOUKuP, J., 2008. The spectrum of invertebrate seed predators that contribute to the control of the rape volunteer seeds (Brassica napus L.). Journal of Plant Diseases and Protection, 21: 261-264.

KulKarni, S.S., DosDall, L.M., Willenborg, C.J., 2015. The role of ground beetles (Coleoptera: Carabidae) in weed seed consumption: a review. Weed Science, 63: $355-376$

Langraf, V., Petrovičová, K., David, S., Ábelová, M., SChlarmanNOvÁ, J., 2017. Body volume in ground beetles (Carabidae) reflects biotope disturbance. Folia Oecologica, 44: 114-120.

LoREAU, M., 1992. Species abundance patterns and the structure of ground-beetle communities. Annales Zoologici Fennici, 28: 49-56.

LUNDGREN, J.G., 2009. Relationship of natural enemies and non-prey foods. Dordrecht: Springer. $453 \mathrm{pp}$.

Lundgren, J.G., Rosentrater, K.A., 2007. The strength of seeds and their destruction by granivorous insects. Arthropod-Plant Interactions, 1: 93-99.

Magura, T., EleK, Z., Tothmeresz, B., 2002. Impacts of non-native spruce reforestation on ground beetles. European Journal of Soil Biology, 38: 291-295.

Naser, B., Bodinet, C., Tegtmeier, M., Lindequist, U., 2005. Thuja occidentalis (Arbor vitae): a review of its pharmaceutical, pharmacological and clinical properties. Evidence-Based Complementary and Alternative Medicine, 2: 69-78.

Nolte, D., Schuldt, A., Gossner, M.M., Ulrich, W., AssMANN, T., 2017. Functional traits drive ground beetle community structures in Central European forests: implications for conservation. Biological Conservation, 213: $5-12$.

Nystrand, O., Granstrom, A., 2000. Predation on Pinus sylvestris seeds and juvenile seedlings in Swedish boreal forest in relation to stand disturbance by logging. Journal of Applied Ecology, 37: 449-463.

O'Rourke, M.E., Heggenstaller, A.H., Liebman, M., Rice, M.E., 2006. Post-dispersal weed seed predation by invertebrates in conventional and low-external-input crop rotation systems. Agriculture Ecosystems and Environment, 116: $280-288$. 
Oxbrough, A., García-Tejero, S., Spence, J., O’Halloran, J., 2016. Can mixed stands of native and non-native tree species enhance diversity of epigaeic arthropods in plantation forests? Forest Ecology and Management, 367: 21-29.

Rogers, R.L., Hinds, W.T., BuschBom, R.L., 1976. A general weight vs. length relationship for insects. Annals of the Entomological Society of America, 69: 387-389.

Saint-Germain, M., Larrivée, M., Drapeau, P., Fahrig, L., BudDLE, C.M., 2005. Short-term response of ground beetles (Coleoptera: Carabidae) to fire and logging in a spruce-dominated boreal landscape. Forest Ecology and Management, 212: 118-126.

SASKA, P., 2008. Granivory in terrestrial isopods. Ecological Entomology, 33: 742-747.

SASKA P., JAROSIK V., 2001. Laboratory study of larval food requirements in nine species of Amara (Coleoptera: Carabidae). Plant Protection Science, 31: 103-110.

Saska, P., Martinkova, Z., HoneK, A., 2010. Temperature and rate of seed consumption by ground beetles (Carabidae). Biological Control, 52: 91-95.

Silvertown, J., Charlesworth, D., 2001. Introduction to plant population biology. 4th ed. Oxford, London, Edin- burgh, Malden, Carlton, Paris: Blackwell Science. 351 p. Talarico, F., Giglio, A., Pizzolotto, R., Brandmayr, P., 2016. A synthesis of feeding habits and reproduction rhythm in Italian seed-feeding ground beetles (Coleoptera: Carabidae). European Journal of Entomology, 113: 325-336.

Thomas, C.F.G., Green, F., Marshall, E.J.P., 1997. Distribution, dispersal and population size of the ground beetles, Pterostichus melanarius (Illiger) and Harpalus rufipes (Degeer) (Coleoptera, Carabidae) in field margin habitats. Biological Agriculture and Horticulture, 15: 337-352.

Westerman, P.R., Hofman, A., Vet, L.E.M., Van Der Werf, W., 2003. Relative importance of vertebrates and invertebrates in epigaeic weed seed predation in organic cereal fields. Agriculture Ecosystems and Environment, 95: 417-425.

White, S.S., Renner, K.A., Menalled, F.D., Landis, D.A., 2007. Feeding preferences of weed seed predators and effect on weed emergence. Weed Science, 55: 606-612.

Received January 16, 2019 Accepted March 23, 2019 